\title{
Infrared Spectra of Methanol, Ethanol, and n-Propanol
}

\author{
Earle K. Plyler
}

\begin{abstract}
The infrared absorption spectra of methanol, ethanol, and $n$-propanol have been measured with prism instruments. Studies have been made of the vapors and of several dilute solutions. The methanol spectra, between 2 to 15 microns, provided a direct comparison with the other two alcohols and confirmed earlier work on the existence of a number of lowintensity bands. The two other alcohols were studied from 2 to 36 microns. The bands have been classified in relation to the $\mathrm{O}-\mathrm{H}, \mathrm{C}-\mathrm{H}, \mathrm{C}-\mathrm{O}$, and $\mathrm{C}-\mathrm{C}$ vibrations within the molecules. The long-wave absorption, in the region beyond 30 microns, for each alcohol, is attributed to the hindered rotation of $\mathrm{OH}$. The object of the present study was to confirm the assignments for methanol and to study and assign the vibrational spectra of ethanol and $n$-propanol.
\end{abstract}

\section{Introduction}

The infrared absorption spectrum of methanol in the vapor state was measured by Borden and Barker $[1]^{1}$ with a grating spectrometer. The stronger bands were resolved so that the rotational structure was apparent. Their observations showed which bands were of the perpendicular and which were of the parallel type. Noether [2], using a prism instrument, also measured the spectrum of methanol and observed several weak bands in addition to those studied by Borden and Barker. Some of these weak bands have been classified as fundamentals and combinations [3]. The object of the present study was to confirm the assignments for methanol and to study and assign the vibrational spectra of ethanol and $n$-propanol. These alcohols have not been measured previously over an extended infrared region, and their spectra have not been classified.

In the present work, the spectra of ethanol and $n$-propanol have been measured from 2 to $40 \mu$ in the vapor state and from 2 to $15 \mu$ in solutions of $\mathrm{CCl}_{4}$ and $\mathrm{CS}_{2}$. Because of the similarity in struc.. ture of these alcohols, the positions of many absorp.tion bands appear in the same regions. No attempt was made to repeat the long wavelength region in methanol, as it would not be possible to improve on the grating measurements of Borden and Barker with a prism spectrograph. However, the 2- to $15-\mu$ region was measured as this region had not been recorded on a double-beam instrument.

\section{Experimental Procedure}

The methanol, ethanol, and $n$-propanol were purified under the direction of F. D. Rossini. They were found to be of high purity, which is essential in order to attribute weak bands to the spectra of the alcohols.

The absorption spectra of the vapors were determined with Perkin-Elmer infrared spectrometers, models $12 \mathrm{~A}$ and $12 \mathrm{C}$, using interchangeable prisms of lithium fluoride, sodium chloride, potassium bromide, and thallium bromide-iodide. This allowed measurements to be made from 2 to approximately $38 \mu$. The properties and use of prisms of thallium

1 Figures in brackets indicate the literature references at the end of this paper. bromide.iodide have been described elsewhere [4]. The standard Perkin..Elmer thermocouple was used as a detector with all but the thallium bromide--iodide prism. Here a Golay detector was substituted for the thermocouple. The spectrometers were equipped with a slit..control device [5], and except for the Go.lay cell, the experimental arrangements were the same as those described in a previous paper [5]. Gas cells of different thicknesses with various pressures were used. The experimental arrangement did not allow the partial pressures of the vapor to be determined as all the cells could not be evacuated.

The absorption spectra of the liquids, diluted with carbon tetrachloride and carbon disulfide, were meas. ured on a Baird recording infrared spectrometer with a sodium chloride prism. Solutions of different concentrations as well as cells of various thicknesses were used. To obtain a higher resolution from 2.6 to $3.6 \mu$, measurements in this region were repeated, with a lithium-fluoride prism in the Perkin-Elmer spectrometer.

\section{Results and Discussion}

The experimental results are given in six figures and two tables. Figure 1 presents the vapor absorption spectra between 2 and $15 \mu$ of methanol, ethanol, and $n$-propanol. In the regions of strong water vapor absorption, bands in the alcohols could not be measured with reasonable accuracy; hence, dotted lines are used to denote the uncertainty of the absorption in these regions.

As shown in figure 1, methanol has a broad region of absorption centering near $7.43 \mu$. This region was restudied with the Perkin-Elmer model 21 spectrometer to take advantage of the higher resolution made possible by the improved amplifier and to eliminate the effect of the water vapor bands. The results are shown in figure 2 .

Figure 3 shows the long wavelength spectra of ethanol and $n$-propanol in the vapor state. Ethanol was examined in the region from 16 to $20 \mu$, using an absorption cell $1 \mathrm{~m}$ thick, but as there was no apppreciable absorption the curve is not shown. In the region from 20 to $38 \mu$ lithium-fluoride, calciumfluoride, and sodium-fluoride reflectors were substituted successively for the usual aluminized mirror. 


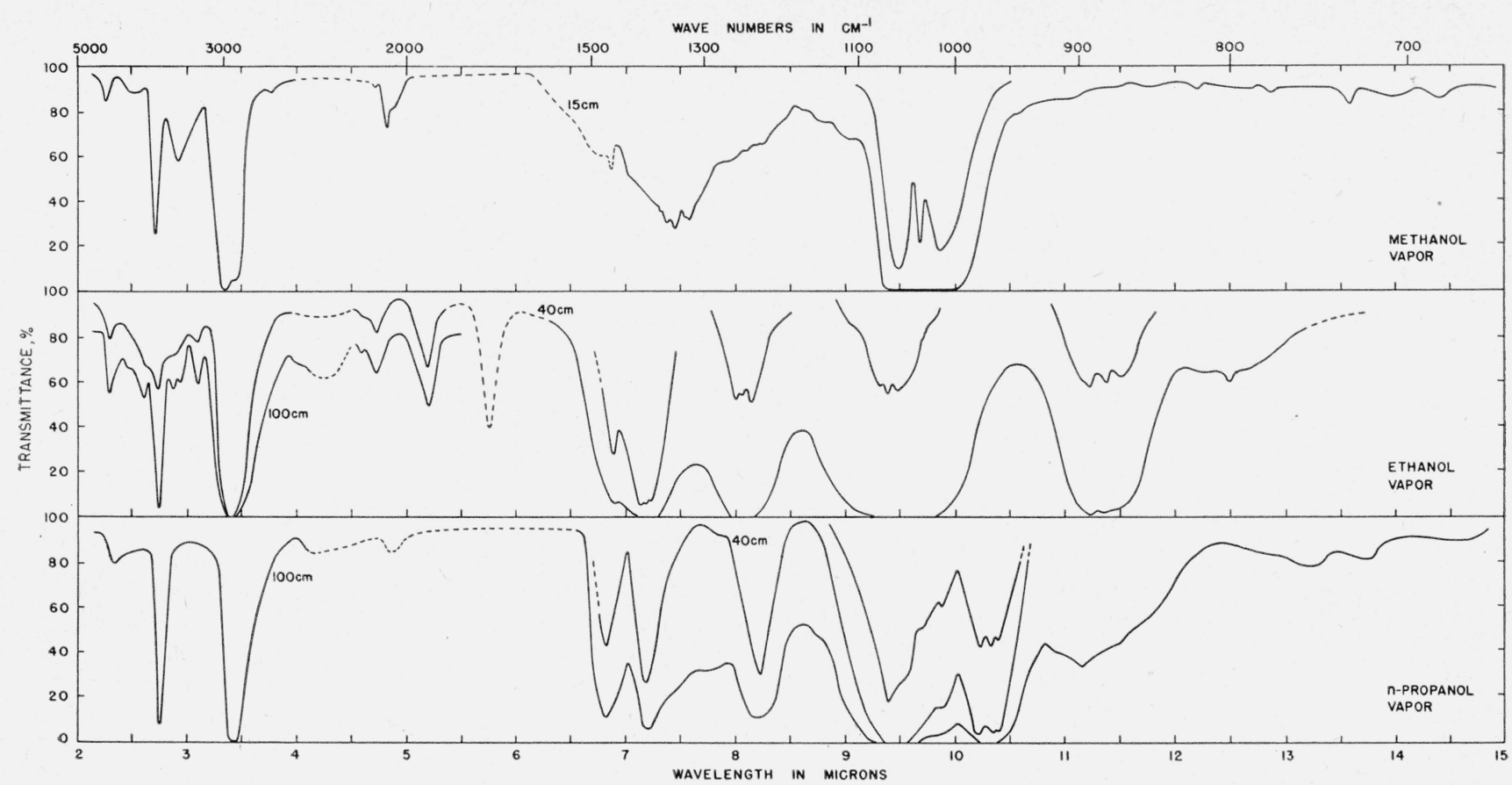

FIGURE 1. Infrared absorption spectra from 2 to $15 \mu$ of methanol, ethanol, and n-propanol in the vapor state.

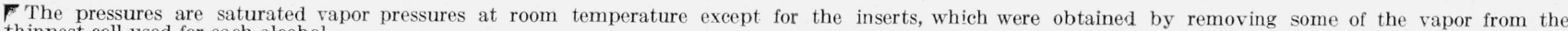
thinnest cell used for each alcohol.

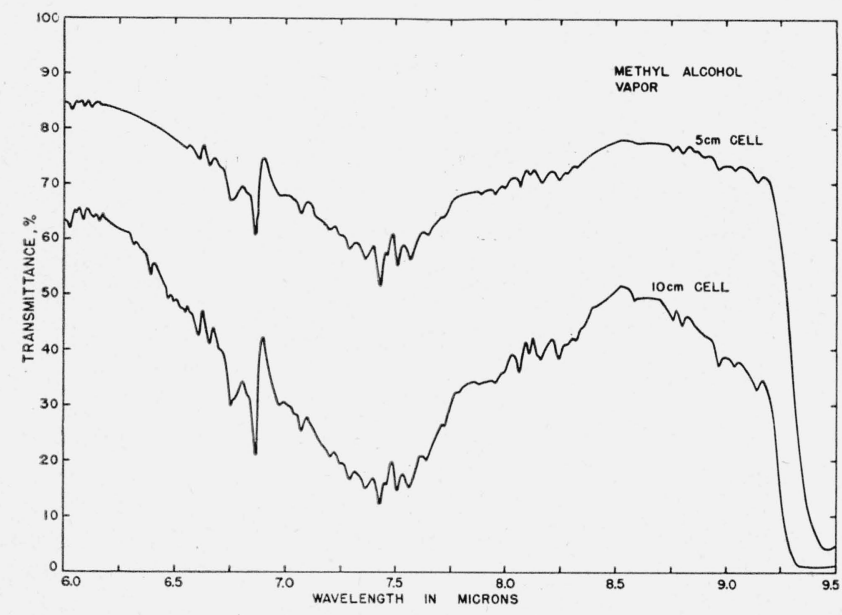

FIGURE 2. Infrared absorption spectrum from 6 to $10 \mu$ of methanol in the vapor state.

The pressure is saturated vapor pressure at room temperature except for the upper curve, which is at a pressure of $6 \mathrm{~cm}$ of $\mathrm{Hg}$.

Although this resulted in some loss in the total reflected energy, the stray radiation was reduced considerably.

Table 1 lists the maxima observed in methanol, ethanol, and $n$-propanol, incorporating some of the results of the higher resolution work in the 6- to $10-\mu$ region of methanol. The wavelength in microns, the wave number in $\mathrm{cm}^{-1}$, and the observed intensity are given for each band. The intensity estimates are divided into five categories, extending from very weak to very strong. In the regions of considerable overlapping, it was not easy to de-

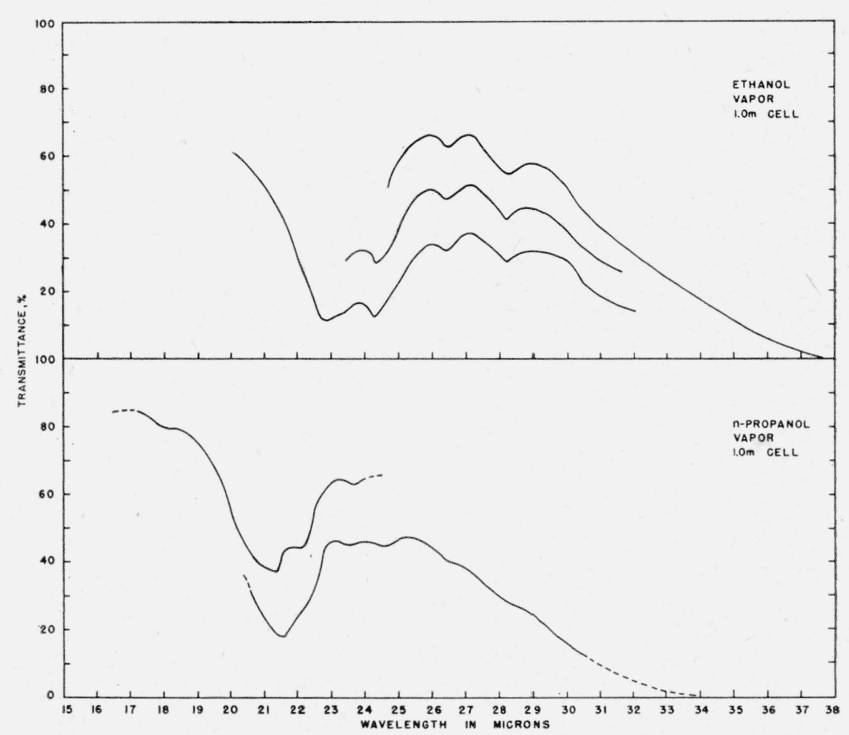

FiguRE 3. Infrared absorption spectra from 15 to $38 \mu$ of ethanol and n-propanol in the vapor state.

The pressures are saturated vapor pressures for the curves of greatest absorption.

termine the band centers. With the exception of the $7.43-\mu$ region of methanol, which is more complicated and whose individual maxima may even be of a rotational nature, all the maxima of absorption are listed. As a result, some of the maxima in table 1 may be parts of bands, such a $P, Q$, or $R$ branches, as well as separate bands. This doubt as to the nature of the maxima in table 1 includes 
TABLE 1. Observed bands of methanol, ethanol, and n-propanol in the vapor state

\begin{tabular}{|c|c|c|c|c|c|c|c|c|}
\hline $\begin{array}{l}\text { Wave- } \\
\text { length }\end{array}$ & $\begin{array}{l}\text { Wave } \\
\text { number }\end{array}$ & Intensity & $\begin{array}{l}\text { Wave- } \\
\text { length }\end{array}$ & $\begin{array}{l}\text { Wave } \\
\text { number }\end{array}$ & Intensity & $\begin{array}{l}\text { Wave- } \\
\text { length }\end{array}$ & $\begin{array}{c}\text { Wave } \\
\text { number }\end{array}$ & Intensity \\
\hline \multicolumn{9}{|c|}{ Methanol } \\
\hline \begin{tabular}{l}
\multicolumn{1}{c}{$\mu$} \\
2.26 \\
2.49 \\
2.71 \\
2.94 \\
3.315 \\
3.346 \\
3.360 \\
3.382 \\
3.395 \\
3.414 \\
3.512 \\
3.75 \\
4.86
\end{tabular} & $\begin{array}{l}\mathrm{cm}^{-1} \\
4425 \\
4016 \\
3687 \\
3401 \\
3017 \\
2989 \\
2976 \\
2959 \\
2946 \\
2929 \\
2847 \\
2667 \\
2057\end{array}$ & $\begin{array}{l}\text { W } \\
\text { VW } \\
\text { M } \\
\text { W } \\
\text { M } \\
\text { M } \\
\text { M } \\
\text { M } \\
\text { S } \\
\text { M } \\
\text { S } \\
\text { VW } \\
\text { W }\end{array}$ & $\begin{array}{c}\mu \\
6.61 \\
6.66 \\
6.76 \\
6.87 \\
6.98 \\
7.07 \\
7.43 \\
7.96 \\
8.07 \\
8.17 \\
8.24 \\
8.54 \\
8.59\end{array}$ & $\begin{array}{l}c m^{-1} \\
1512 \\
1501 \\
1479 \\
1455 \\
1432 \\
1415 \\
1346 \\
1256 \\
1239 \\
1224 \\
1213 \\
1171 \\
1164\end{array}$ & $\begin{array}{l}\text { VW } \\
\text { VW } \\
\text { M } \\
\text { M } \\
\text { VW } \\
\text { VW } \\
\text { S } \\
\text { VW } \\
\text { VW } \\
\text { VW } \\
\text { VW } \\
\text { VW } \\
\text { VW }\end{array}$ & $\begin{array}{r}\mu \\
8.75 \\
8.80 \\
8.97 \\
9.04 \\
9.14 \\
9.47 \\
9.68 \\
10.57 \\
12.19 \\
12.83 \\
13.58 \\
14.40\end{array}$ & $\begin{array}{c}\mathrm{cm}^{-1} \\
1142 \\
1136 \\
1114 \\
1106 \\
1094 \\
1056 \\
1033 \\
946 \\
820 \\
779 \\
736 \\
694\end{array}$ & $\begin{array}{l}\text { VW } \\
\text { VW } \\
\text { VW } \\
\text { VW } \\
\text { VW } \\
\text { VW } \\
\text { S } \\
\text { VW } \\
\text { VW } \\
\text { VW } \\
\text { VW } \\
\text { VW }\end{array}$ \\
\hline \multicolumn{9}{|c|}{ Ethanol } \\
\hline $\begin{array}{l}2.30 \\
2.48 \\
2.593 \\
2.71 \\
2.84 \\
2.92 \\
3.08 \\
3.340 \\
3.359 \\
3.42\end{array}$ & $\begin{array}{l}4348 \\
4032 \\
3856 \\
3687 \\
3521 \\
3425 \\
3248 \\
2994 \\
2977 \\
2924\end{array}$ & $\begin{array}{l}\text { W } \\
\text { VW } \\
\text { W } \\
\text { M } \\
\text { VW } \\
\text { VW } \\
\text { W } \\
\text { S } \\
\text { S } \\
\text { S }\end{array}$ & $\begin{array}{l}3.443 \\
3.46 \\
3.93 \\
4.25 \\
4.63 \\
4.74 \\
5.20 \\
5.76 \\
6.87\end{array}$ & $\begin{array}{l}2904 \\
2890 \\
2513 \\
2353 \\
2160 \\
2110 \\
1923 \\
1736 \\
1456\end{array}$ & $\begin{array}{l}\mathrm{S} \\
\mathrm{M} \\
\mathrm{VW} \\
\mathrm{W} \\
\mathrm{VW} \\
\mathrm{W} \\
\mathrm{W} \\
\mathrm{M} \\
\mathrm{M}\end{array}$ & $\begin{array}{r}7.19 \\
8.05 \\
9.37 \\
11.36 \\
12.49 \\
23.4 \\
26.5 \\
28.3 \\
\text { × } 37\end{array}$ & $\begin{array}{r}1391 \\
1242 \\
1067 \\
877 \\
801 \\
427 \\
377 \\
353 \\
267\end{array}$ & $\begin{array}{l}\mathrm{S} \\
\mathrm{S} \\
\mathrm{VS} \\
\mathrm{S} \\
\mathrm{W} \\
\mathrm{M} \\
\mathrm{VW} \\
\mathrm{VW} \\
\mathrm{S}\end{array}$ \\
\hline \multicolumn{9}{|c|}{$n$-Propanol } \\
\hline $\begin{array}{l}2.33 \\
2.71 \\
3.358 \\
3.395 \\
3.415 \\
3.458 \\
4.18 \\
4.87 \\
6.83\end{array}$ & $\begin{array}{l}4291 \\
3687 \\
2978 \\
2946 \\
2929 \\
2892 \\
2392 \\
2053 \\
1464\end{array}$ & $\begin{array}{l}\text { W } \\
\text { M } \\
\text { S } \\
\text { S } \\
\text { S } \\
\text { M } \\
\text { VW } \\
\text { VW } \\
\text { M }\end{array}$ & $\begin{array}{r}7.18 \\
7.84 \\
8.21 \\
9.38 \\
9.55 \\
9.68 \\
9.87 \\
10.31\end{array}$ & $\begin{array}{r}1393 \\
1276 \\
1218 \\
1066 \\
1047 \\
1033 \\
1013 \\
971\end{array}$ & $\begin{array}{l}\text { S } \\
V W \\
S \\
V S \\
M \\
W \\
W \\
S\end{array}$ & $\begin{array}{l}11.13 \\
13.20 \\
13.75 \\
18.0 \\
21.6 \\
23.7 \\
24.6 \\
\text { \& } 35\end{array}$ & $\begin{array}{l}898 \\
758 \\
727 \\
555 \\
463 \\
422 \\
407 \\
286\end{array}$ & $\begin{array}{l}M \\
W \\
W \\
\text { VW } \\
\text { M } \\
\text { VW } \\
\text { VW } \\
\text { S }\end{array}$ \\
\hline
\end{tabular}

a Centers of band beyond region of observations.

those in the region of $3.3 \mu$ for all three alcohols and the $9.5-\mu$ region for $n$-propanol.

Figures 1 and 3 show that there are regions in which the vapor-phase spectra of all three molecules are similar. In methanol, the regions of intense absorption occur near 2.7, 3.4, 7.5, and $9.6 \mu$. These are produced according to Herzberg [3] by the $\mathrm{O}-\mathrm{H}$ and $\mathrm{C}-\mathrm{H}$ stretching, $\mathrm{C}-\mathrm{H}$ and $\mathrm{O}-\dot{\mathrm{H}}$ bending and $\mathrm{C}-\mathrm{O}$ stretching vibrations, respectively. These recur in the heavier alcohols with little shift. In particular, the $\mathrm{OH}$ band at $2.7 \mu$ and the band due to the $\mathrm{C}-\mathrm{H}$ stretching vibrations at $3.4 \mu$ appear at almost the same position on all three curves.

The region around $3 \mu$ has been studied under the higher resolution provided by a $\mathrm{LiF}$ prism. The results are shown in figures 4 and 5 . The methanol curve, figure 4 , shows the symmetric vibration of the $\mathrm{CH}_{3}$ group at $2,847 \mathrm{~cm}^{-1}(3.5 \mu)$, the $P, Q$, and $R$ branches being well resolved. The other bands in the region of 3.3 and $3.4 \mu$ are considerably overlapped, and it is difficult to determine their centers. In the ethanol and $n$-propanol curves, figure 5 , it is more difficult to untangle the $\mathrm{C}-\mathrm{H}$ vibrations in the $3.4-\mu$ region because there are stretching vibrations that occur in the $\mathrm{CH}_{2}$ and $\mathrm{CH}_{3}$ groups that give rise to five fundamentals for ethanol and seven fundamentals for $n$-propanol. Figure 4 also shows the $2.7-\mu \mathrm{OH}$ band resolved into $P$ and $R$ branches.

The $2.7-\mu \mathrm{OH}$ bands in ethanol and $n$-propanol were also measured. However, the resolution of the prism instrument was insufficient to separate clearly the $P$ and $R$ branches of the band. This problem will be pursued further with a grating spectrometer.

When the spectra of the three alcohols are studied in solutions of $\mathrm{CCl}_{4}$ and $\mathrm{CS}_{2}$, there are considerable changes in absorption, particularly in the two regions due to the $\mathrm{OH}$ band. Figure 6 shows some results from 2 to $15 \mu$. At the concentration of 1:20 the $\mathrm{O}-\mathrm{H}$ stretching vibration is shifted to $2.9 \mu$, a position characteristic of associated ("hydrogenbonded") $\mathrm{OH}$. At a concentration of $1: 4$ in $\mathrm{CCl}_{4}$ the unassociated $\mathrm{OH}$ band, which in the vapor occurs at $2.71 \mu$, is barely observable near $2.74 \mu$.

At lower concentrations, the $2.74-\mu$ band is clearly resolved. Measurements with a LiF prism are shown in figure 7 . The alcohols were diluted with carbon tetrachloride to concentrations 1:40 and 1:400 by volume, and cell thicknesses of 0.5 and 5.0 $\mathrm{mm}$, respectively, were used. Thus the resultant absorption in each cell was due to practically the same relative number of alcohol molecules, and the effect of the concentration upon the position and intensity of the hydroxyl band could be examined under comparable conditions. When the dilution 
was one part in forty, the $\mathrm{OH}$ band in the $2.74-\mu$ region was present as well as the associated band at $2.97 \mu$. However, when the concentration was reduced to one part in 400 , the $2.97-\mu$ band disappeared, and the $\mathrm{OH}$ absorption at $2.74 \mu$ increased in intensity. No significant changes were observed in the bands in the region of $3.4 \mu$. The degree of association for different concentrations appears to vary somewhat with the particular alcohol. However, this effect has not been studied in detail in the present work. Smith and Creitz [6] have studied the effect of association in 11 alcohols. They have shown that the degree of association depends on the particular alcohol and the amount of

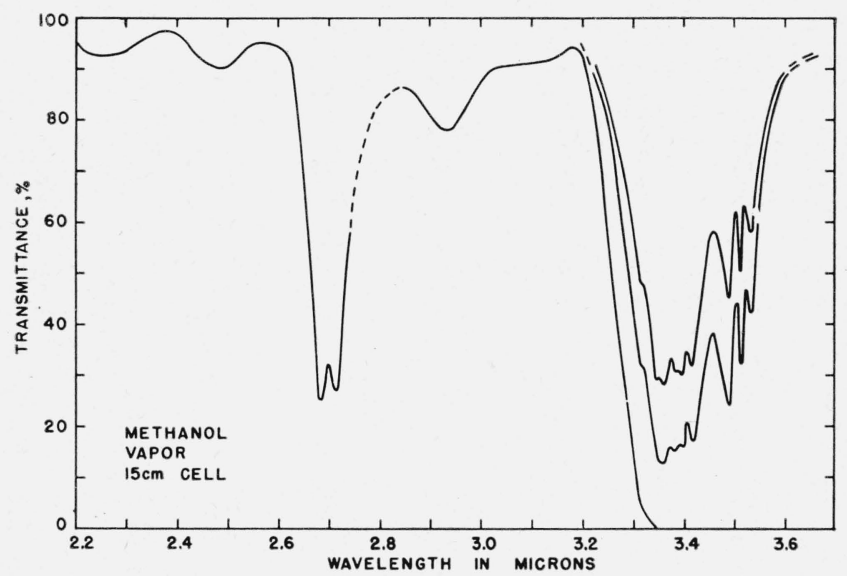

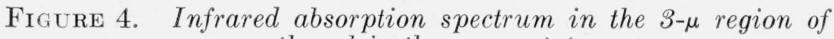
methanol in the vapor state.

The pressure is saturated vapor pressure except for the inserts, which were obtained by removing some of the vapor from the cell. A lithium fluoride prism was used. dilution. Their work also supports the idea that some of the heavier alcohols have $\mathrm{OH}$ bands at 2.76 and $2.86 \mu$.

In the region of the associated $\mathrm{OH}$ band $(2.9 \mu)$, there is a weak band in the vapor phase spectrum of methanol (figs. 1, 4). When this region was remeasured using a 5-cm cell with a $9.5-\mathrm{cm}$ gas pressure of methanol, the cell having been filled under vacuum, the $2.9-\mu$ band disappeared. A possible explanation for the presence of this band, attributed to association, is that a thin film of a

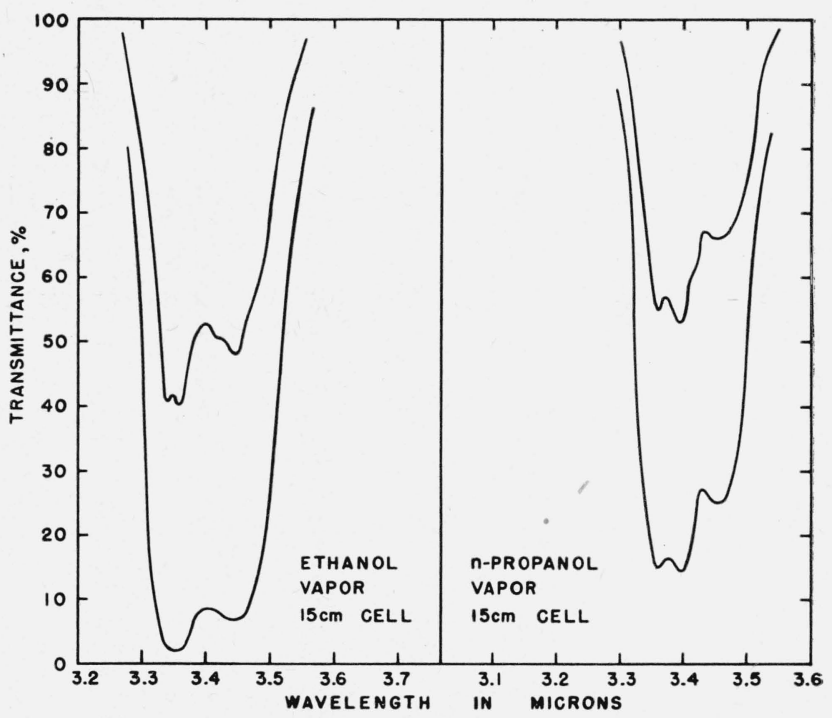

FiguRE 5. Infrared absorption spectra in the 3.4- $\mu$ region of ethanol and $n$-propanol in the vapor state.

The pressures are saturated vapor pressures except for the inserts, which were obtained by removing some of the vapor from the cell. A lithium fluoride prism was used.

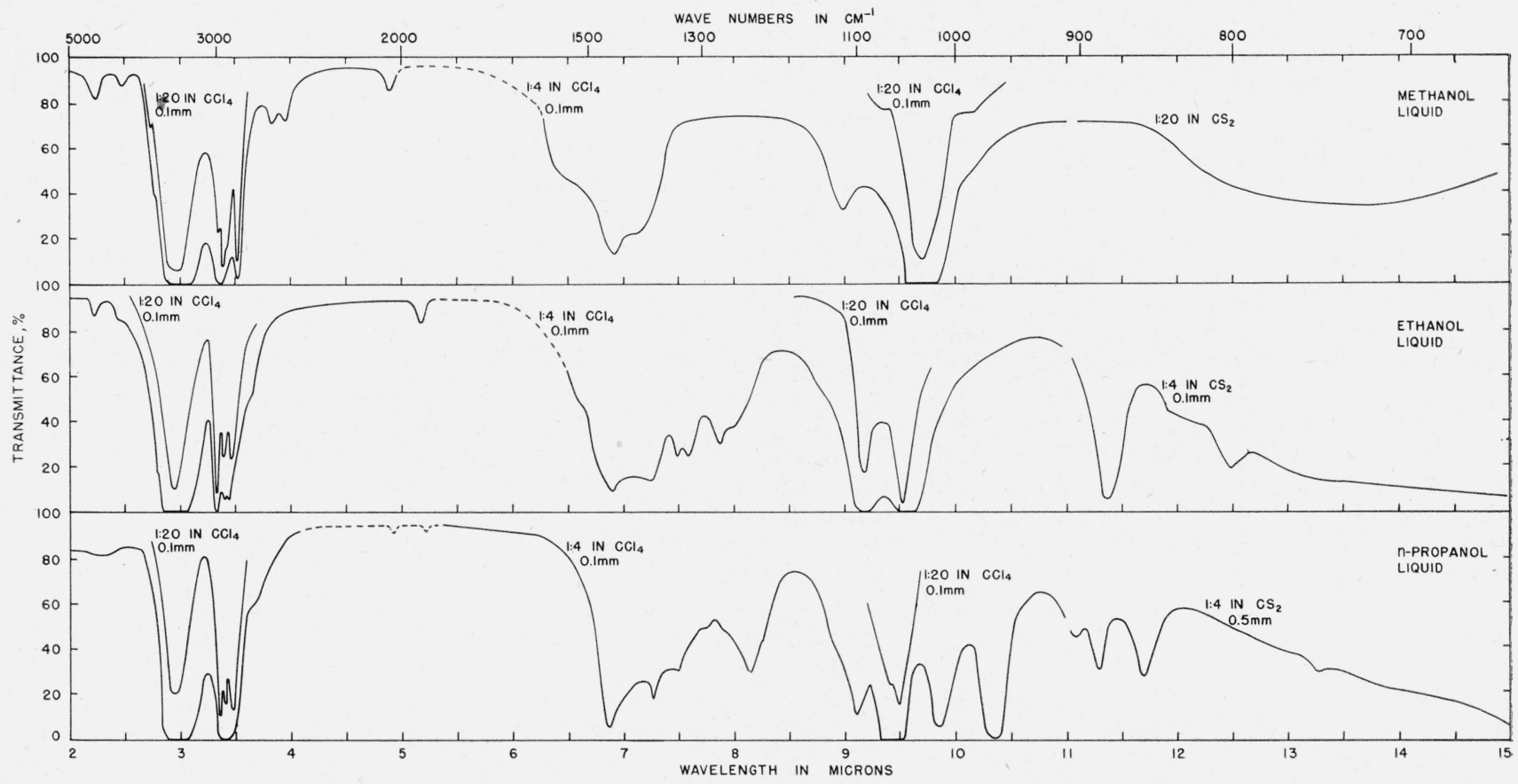

FIGURE 6. Infrared absorption spectra from 2 to $15 \mu$ of methanol, ethanol, and n-propanol diluted as indicated in carbon tetrachloride and carbon disulphide. 


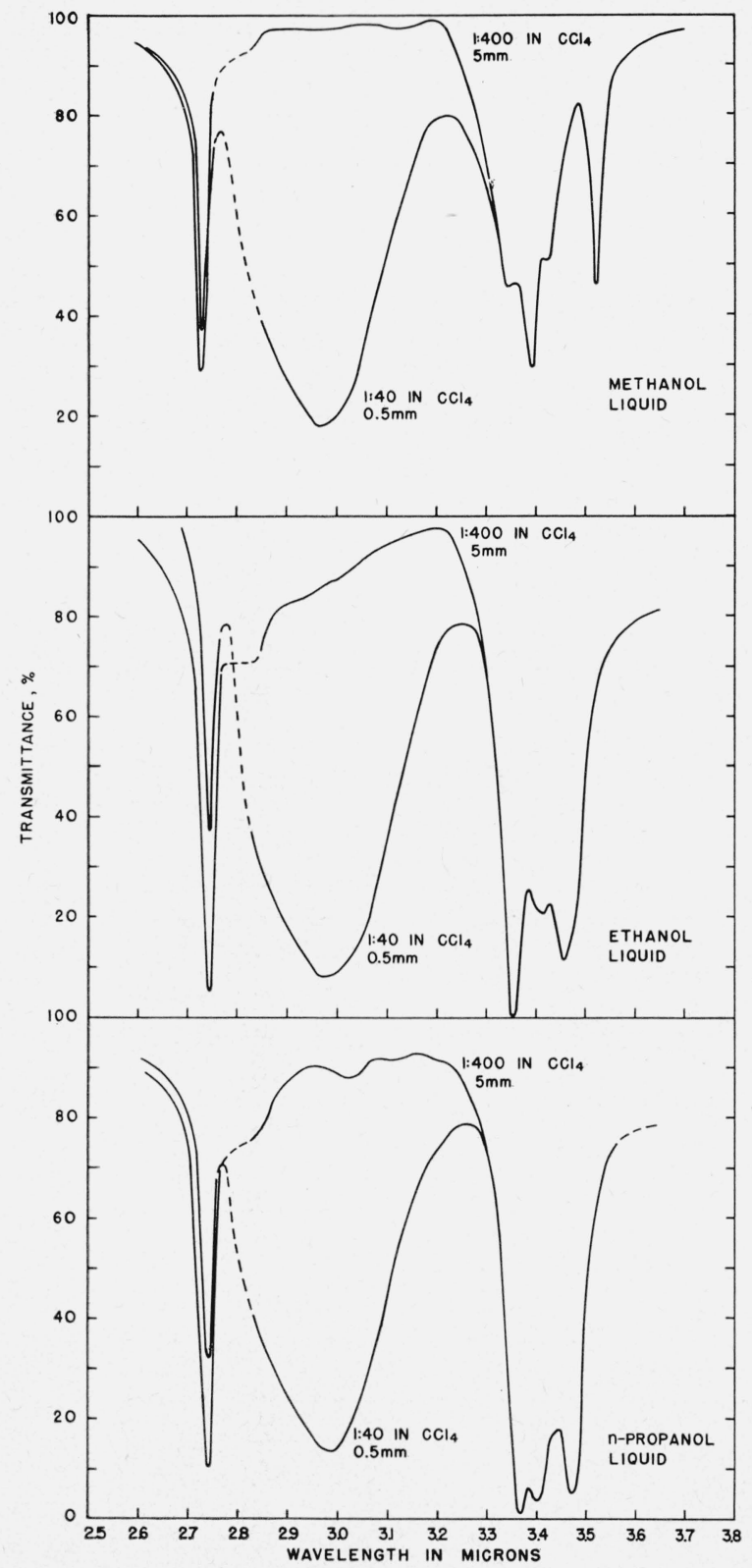

FIGURE 7. Infrared absorption spectra in the $3-\mu$ region of methanol, ethanol, and n-propanol diluted in carbon tetrachloride.

A lithium fluoride prism w:s used.

mixture of water and alcohol was deposited on the windows of the cell, and the band is due to this thin film.

In the bands that are attributed to the $\mathrm{C}-\mathrm{H}$ vibrations there are only small changes in the positions of the bands when the spectra of the vapors are compared with those of the solutions. However, in the region of $\mathrm{O}-\mathrm{H}$ bendings from 6.5 to $8.5 \mu$ there is considerable difference. In the vapor state or highly dilute solution of methanol there is appreciable absorption in the $7.43-\mu$ region that has been assigned to the $\mathrm{O}-\mathrm{H}$ bending frequency. The spectrum of a fairly concentrated solution shows no absorption in this region, but an intense band appears at $6.9 \mu$ with a less intense band at $7.15 \mu$. This difference could be produced by the effect of the association of the $\mathrm{O}-\mathrm{H}$ groups on the bending vibration of $\mathrm{O}-\mathrm{H}$. In solution and in the pure liquid all three alcohols have considerable absorption from 12.5 to $15 \mu$. None of the vapors show measurable bands in this region.

The observations of the vapor-solution shifts of the $7.4 \cdots \mu$ band confirm in general the assignments in $\mathrm{CH}_{3} \mathrm{OH}$ given by Herzberg [3] and listed in table 2 . A further general confirmation results from a reasonable explanation of the many weak maxima between 6 to $10 \mu$. The twisting of the $\mathrm{OH}$ with respect to $\mathrm{CH}_{3},\left(\nu_{8}{ }^{\prime \prime}\right)$, gives rise, in the fundamental, to a broad absorption centered around $40 \mu$. The first overtone of this band shows a large number of rotational lines in the region from 11.6 to $26.3 \mu$ that have been measured by Borden and Barker [1]. They suggest that the torsional oscillations have become a rotation resulting in the spreading out of the band. Combinations of the $\mathrm{O}-\mathrm{H}$ twisting with the $\mathrm{C}-\mathrm{O}$ stretching $\left(\nu_{4}\right)$ and the $\mathrm{CH}_{3}$ rocking vibrations $\left(\nu_{7}\right)$ might well give rise to the complicated structure between 6.6 and $9.2 \mu$. For example, if the potential energy that hinders rotation is sufficiently small, the interaction with these other modes might further reduce it and the result would be nearly free rotation. This would account for the maxima in the 6.6 to $9.2-\mu$ region. For a more definite assignment, high-resolution studies and a detailed calculation of the oscillatory potential and its interaction with the hindered rotation is required.

Some of the fundamentals in ethanol and propanol may now be assigned by comparison with and extension of the methanol assignments. These are also given in table 2. The ethanol spectrum should have nine more fundamentals than methanol. Of these five are of interest here. Three refer to internal vibrations of the $\mathrm{CH}_{2}$ group. The $\mathrm{C}-\mathrm{C}-\mathrm{O}$ skeletal vibrations will give rise to three bands that consist of one bending and two stretching vibrations. The band at $23.4 \mu$ is assigned to this bending vibration, and the two bands observed at 9.4 and $11.4 \mu$ are related to the $\mathrm{C}-\mathrm{O}$ and $\mathrm{C}-\mathrm{C}$ stretching vibrations. The $\mathrm{O}-\mathrm{H}$ twisting vibration that also exists in methanol occurs in the region of $40 \mu$, but as its band falls at the limit of transmission of the thallium bromide-iodide prism, its position could not be accurately determined. The two small bands at 26.4 and $28.2 \mu$ may be part of the first harmonic of the longer wavelength band, but only a few small structures that may be a part of this rotation were obserbed in the ethanol spectrum. The spectrum from 12 to $26 \mu$ is considerably different from that observed for methanol, which has many rotational lines in this region.

In the $8-\mu$ region, the ethanol bands are somewhat better defined than those for methanol. There are three fairly intense bands at $6.87,7.19$ and $8.05 \mu$. These are assigned respectively to the asymmetric $\mathrm{C}-\mathrm{H}$ bending in $\mathrm{CH}_{2}$ and $\mathrm{CH}_{3}$, to the $\mathrm{O}-\mathrm{H}$ bending; 
TABLE 2. Band assignments for methanol, ethanol, and and n-propanol

\begin{tabular}{|c|c|c|c|c|c|}
\hline Assignment & $\begin{array}{l}\text { Type of } \\
\text { vibration }\end{array}$ & $\begin{array}{c}\text { Wave } \\
\text { number }\end{array}$ & Assignment & $\begin{array}{l}\text { Type of } \\
\text { vibration }\end{array}$ & $\begin{array}{l}\text { Wave } \\
\text { number }\end{array}$ \\
\hline \multicolumn{6}{|c|}{ Methanol } \\
\hline $\begin{array}{l}\nu_{1} \mathrm{OH} \\
{ }_{5}{ }^{\prime} \mathrm{CH}_{3} \\
\nu_{5}^{\prime}, \prime \\
2 \nu_{6}^{\prime \prime \prime} \\
\nu_{2} \mathrm{CH}^{\prime \prime} \\
2 \nu_{4} \\
\nu_{6}{ }^{\prime \prime} \mathrm{CH}_{3} \\
\nu_{3} \mathrm{CH}_{3}\end{array}$ & $\begin{array}{c}\text { Stretching } \\
\text { do } \\
\\
\end{array}$ & \begin{tabular}{|l|}
\multicolumn{1}{c|}{$c m^{-1}$} \\
3682 \\
2976 \\
Overlapped \\
Do. \\
$2 S 46$ \\
2057 \\
1479 \\
$1455\} \quad 1467$
\end{tabular} & $\begin{array}{l}\nu_{6}, \mathrm{CH}_{3} \\
\nu_{8}, \mathrm{OH}^{\prime} \\
\nu_{7}^{\prime \prime}, \mathrm{CH}^{\prime} \\
\nu_{7} \mathrm{CH}_{3} \\
\nu_{4} \mathrm{CO} \\
\nu_{8}^{\prime \prime} \mathrm{OH}\end{array}$ & $\begin{array}{c}\text { Bending } \\
\text { do } \\
\text { Rocking } \\
\text { do } \\
\text { Stretching } \\
\text { Twisting. }\end{array}$ & $\begin{array}{l}\quad \mathrm{cm}^{-1} \\
1427 \\
1346 \\
1171 \\
1056 \\
1033 \\
a 270\end{array}$ \\
\hline \multicolumn{6}{|c|}{ Ethanol } \\
\hline $\begin{array}{l}\nu_{1} \mathrm{OH} \\
\nu_{5}{ }^{\prime} \mathrm{CH}_{2}, \\
\mathrm{CH}_{3} \\
\nu_{5}^{\prime \prime} \\
2 \nu_{6}^{\prime \prime} \\
2 \nu_{4} \\
\nu_{4}+\nu_{10} \\
2 \nu_{10} \\
\nu_{6}{ }^{\prime} \mathrm{CH}_{2}, \\
\mathrm{CH}_{3}\end{array}$ & $\begin{array}{l}\text { Stretching } \\
- \text { do }\end{array}$ & \begin{tabular}{|l|}
3689 \\
2994 \\
\\
Overlapped \\
Do. \\
2110 \\
1923 \\
1736 \\
1456
\end{tabular} & $\begin{array}{l}\nu_{8}, \mathrm{OH} \\
\nu_{9} \mathrm{CH}{ }_{2} \\
\nu_{4} \mathrm{CO} \\
\nu_{10} \mathrm{CCl} \\
2 \nu_{11} \mathrm{CCO} \\
\nu_{11} \mathrm{CCO} \\
\nu_{8} \prime \mathrm{OH}\end{array}$ & $\begin{array}{c}\text { Bending } \\
\text { do } \\
\text { Stretching } \\
\text { do } \\
\text { Bending } \\
\text { do } \\
\text { Twisting. }\end{array}$ & $\begin{array}{c}1391 \\
1242 \\
1067 \\
877 \\
801 \\
427 \\
a 267\end{array}$ \\
\hline \multicolumn{6}{|c|}{$n$-Propanol } \\
\hline 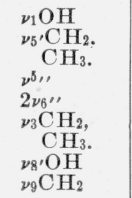 & $\begin{array}{l}\text { Bending } \\
\text { do }\end{array}$ & $\begin{array}{c}3689 \\
2978 \\
\\
\text { Overlapped } \\
\text { Do.. } \\
1464 \\
1393 \\
1218\end{array}$ & $\begin{array}{l}\nu_{4} \mathrm{CO} \\
\nu_{10}, \mathrm{CC} \\
\nu_{10} \prime \prime \mathrm{CC} \\
2 \nu_{11} \mathrm{CCCO} \\
\nu_{11} \mathrm{CCCO} \\
\nu_{8}^{\prime \prime} \mathrm{OH}\end{array}$ & $\begin{array}{l}\text { Stretching } \\
\text { do } \\
\text { do } \\
\text { Bending } \\
\text { do } \\
\text { Twisting }\end{array}$ & $\begin{array}{r}1066 \\
1013 \\
971 \\
898 \\
463 \\
a 286\end{array}$ \\
\hline
\end{tabular}

a Estimated value.

and to the bending of the $\mathrm{CH}_{2}$ hydrogens symmetrically about the $\mathrm{C}-\mathrm{C}$ axis. The same bands appear with very little shift in $n$-propanol, with the 6.83 - and $8.21-\mu$ bands showing considerable increased intensity. This is confirmation of their assignment to the $\dot{\mathrm{CH}}_{2}$ group since there is one additional such group in the heavier molecule. In both of the higher alcohols there is indubitably some overlapping of the many fundamentals in this region and therefore some uncertainty, but the principal features appear to be as assigned.

The remaining strong absorptions in $n$-propanol must be due to the skeletal vibrations. In the $\mathrm{C}-\mathrm{C}-\mathrm{C}-\mathrm{O}$ stretching region there are three strong bands between 9 to $10.5 \mu$, one of which $(9.38$ $\mu$ ) coincides closely with ethanol and is assigned to $\mathrm{C}-\mathrm{O}$. The skeletal bending vibration is observed at $21.6 \mu$. The long-wave absorption, as in ethanol, is assigned to $\mathrm{OH}$ torsion.

The author thanks Shea L. Kruegel and Mary A. Lamb for their assistance in this work.

\section{References}

[1] A. Borden and E. F. Barker, J. Chem. Phys, 6, 553 (1938).

[2] H. D. Noether, J. Chem. Phys. 10, 693 (1942).

[3] G. Herzberg, Infrared and Raman spectra of polyatomic molecules, p. 335 (D. Van Nostrand Co., Inc., New York, N. Y., 1945).

[4] E. K. Plyler, J. Opt. Soc. Am. 3\%, 746 (1947).

[5] E. K. Plyler, R. Stair, and C. J. Humphreys, J. Research NBS 38, 211 (1947) RP1769.

[6] F. A. Smith and E. C. Creitz, J. Research NBS 46, 145 (1951) RP2187.

Washington, November 13, 1951. 